\title{
CMEARTICLE
}

\section{The adult patient with headache}

Vivien Min Er Lee ${ }^{1}$, MBBS, Lai Lai Ang², MBBS, MMed, Derek Tuck Loong Soon ${ }^{3}$, PhD, FRCP, Jonathan Jia Yuan $\underline{\mathrm{Ong}^{3}}$, MMed, FRCP, Victor Weng Keong $\underline{\mathrm{Loh}}^{1}$, MCFP, MHPE

Ms Lim, a 46-year-old music teacher, visited your clinic complaining about a headache that had affected her ability to teach. She told you that she has had a long history of migraine since her 30s. Typically, she had pulsatile, unilateral severe headaches which were associated with photophobia, phonophobia, nausea and vomiting. She used to have these headaches once every one to two months, but they had occurred on most days over the last three to four months, with each episode lasting about half a day. Self-medicating with diclofenac and Panadol almost daily for the past three months had mostly relieved the symptoms. Her neurological examination was normal and a fundoscopic examination did not reveal any papilloedema. The systemic review was unremarkable. She asked you for stronger analgesic medication, as her headaches were becoming unbearable.

\section{WHAT IS HEADACHE?}

Headache is the symptom of pain anywhere in the region of the head or neck.

\section{HOW RELEVANT IS THIS TO MY PRACTICE?}

Headache is a common presentation in primary care. It affects patients' work, relationships and social activities, and exacts a significant social and financial cost. ${ }^{(1-6)}$ While headaches make up $5 \%$ of the global disease burden in terms of disability, ${ }^{(7)}$ the Singapore lifetime prevalence of headache has been reported to be $82.7 \%$, and that of migraine $9.3 \%{ }^{(8)}$ In addition, it appears that medication overuse headache is under-recognised and preventive medication for migraine is underprescribed locally. ${ }^{(9)}$ In this article, we present a practical approach to the management of headache for adults in primary care, with a focus on the management of tension-type headache (TTH), migraine and headache from medication overuse.

\section{WHAT CAN I DO IN MY PRACTICE? Exclude secondary causes}

The physician should first exclude secondary headache in the patient who presents with a headache. A coexisting pathology causing the headache accounts for approximately $10 \%$ of all causes of headache. ${ }^{(10)}$ A careful history and focused neurologic examination (Fig. 1) is usually adequate to exclude secondary headache. The SNOOP4 mnemonic (Table I) may be used to elicit red flags that are mostly secondary causes of headache. These would necessitate referral to either the emergency department or a specialist, depending on the sense of urgency and index of suspicion.

\section{Exclude local causes}

Local causes of headache should be considered, including toothache, sinus, eye, ear or neck disorders; attention should be paid to the neuralgias, such as trigeminal neuralgia in the patient with hemifacial pain. If these are present, the patient should be treated and/or referred accordingly.

\section{Categorise the primary headache disorder}

Having ensured the absence of red flags and local causes, consider a primary headache disorder as the likely diagnosis. The type of primary headache can be categorised based on phenotype. This may be determined by attack frequency, duration, concomitant symptoms and whether cranial autonomic symptoms are present (Table II). The third edition of the International Classification of Headache Disorders (ICHD-3) can be a helpful reference (Table III). ${ }^{(11)}$

Broadly speaking, the frequency of headache attacks may be described as episodic ( $<5$ days/month), chronic ( $\geq 15$ days/month) or daily. In addition, the different types of headaches vary in duration. TTH may last from 30 minutes to seven days, a migraine headache usually lasts $4-72$ hours, and a cluster headache typically lasts 15-180 minutes.

The character of the headache aids in further differentiation. TTH is usually bilateral, has a pressing quality, is not typically aggravated by physical activity, and is mild to moderate in intensity. It predominantly affects females. On the other hand, migraine is typically unilateral, pulsatile or throbbing. It is sensitive to movement, may be associated with photophobia, nausea and vomiting, and is of moderate to severe intensity. Up to one-third of migraines may be associated with a visual or sensory aura. Most patients have a positive family history. Cluster headache, also known as 'suicide headache',

${ }^{1}$ Department of Family Medicine, National University Health System, ${ }^{2}$ Clementi Polyclinic, National University Polyclinics, ${ }^{3}$ Department of Neurology, National University Health System, Singapore

Correspondence: Dr Vivien Lee Min Er, Department of Family Medicine, National University Health System, 1E Kent Ridge Road, NUHS Tower Block, Level 9, Singapore 119228. vivien_lee@nuhs.edu.sg 


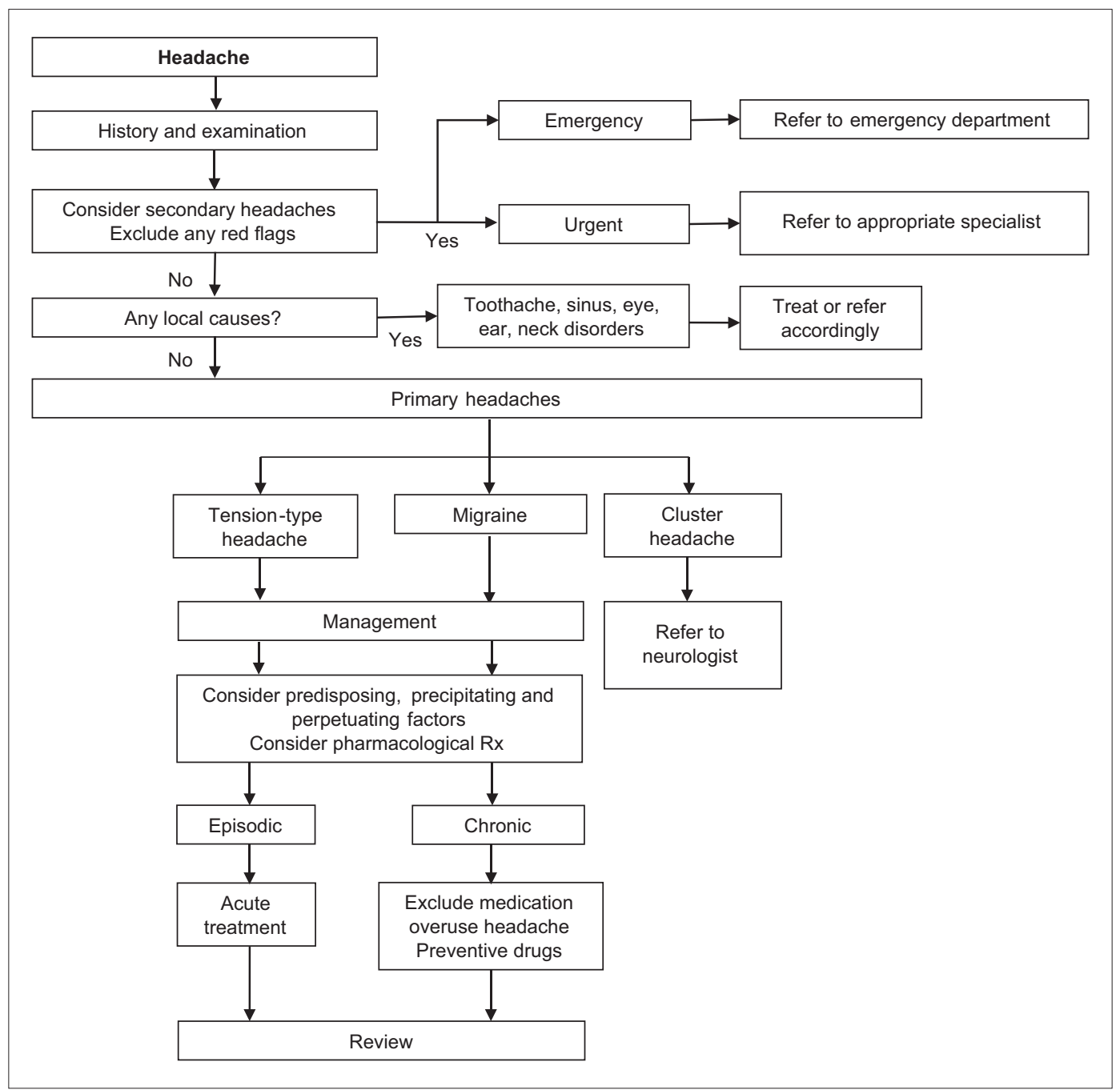

Fig. 1 Flowchart shows the stepwise diagnosis and management of headaches.

Table I. The SNOOP4 mnemonic for excluding red flags (secondary causes of headache).

\begin{tabular}{|c|c|c|}
\hline & Clinical feature(s) & Need to exclude \\
\hline $\mathbf{S}$ & $\begin{array}{l}\text { Systemic symptoms: fever, } \\
\text { chills, myalgia, weight loss }\end{array}$ & Metastasis, infection \\
\hline $\mathbf{N}$ & $\begin{array}{l}\text { Neurological symptoms or } \\
\text { deficits }\end{array}$ & $\begin{array}{l}\text { Stroke, mass lesion, } \\
\text { encephalitis }\end{array}$ \\
\hline 0 & $\begin{array}{l}\text { Older age at onset } \\
\text { (>50 years) }\end{array}$ & $\begin{array}{l}\text { Temporal arteritis, } \\
\text { glaucoma, mass lesion }\end{array}$ \\
\hline $\mathbf{0}$ & $\begin{array}{l}\text { Onset, thunderclap } \\
\text { headache onset }\end{array}$ & Bleed \\
\hline $\mathbf{P}$ & Papilloedema & $\begin{array}{l}\text { Raised intracranial } \\
\text { pressure }\end{array}$ \\
\hline $\mathbf{P}$ & Positional & Intracranial hypotension \\
\hline $\mathbf{P}$ & $\begin{array}{l}\text { Precipitated by Valsalva } \\
\text { manoeuvre or exertion }\end{array}$ & $\begin{array}{l}\text { Raised intracranial } \\
\text { pressure }\end{array}$ \\
\hline $\mathbf{P}$ & $\begin{array}{l}\text { Progressive headache or } \\
\text { substantial pattern change }\end{array}$ & Any secondary cause \\
\hline
\end{tabular}

is strictly unilateral and usually occurs around the eye. It is associated with prominent cranial autonomic symptoms such as hyperlacrimation, conjunctival injection, rhinorrhoea, nasal congestion, ptosis and changes in pupillary size. Circadian rhythmicity is the hallmark of a cluster headache: typically, periods of relatively short-lived (clusters of 15-180 minutes) but intensely painful attacks occur between periods of remission. Males are predominantly affected.

ID Migraine is a three-item (disabling headache, photophobia and/or vomiting) tool that may be used to screen for migraine. The presence of two out of three items positively predicts migraine by $93 \%$ (Box 1). ${ }^{(12)}$ Similarly, the presence of four out of five criteria in the POUND mnemonic (Box 2) gives a likelihood ratio of 24 for possible migraine. ${ }^{(13)}$ Both POUND and ID Migraine are user-friendly screening tools that encompass the major criteria in the ICHD-3 diagnostic criteria for migraine (Table III).

\section{Management of primary headache}

The majority of patients with primary headache may be safely managed in the outpatient setting. In managing primary headache, look for predisposing, precipitating and/or perpetuating factors in the patient's history. Inadequate hydration, irregular meals, irregular sleep, excessive alcohol, excessive caffeine and/or lack of exercise may all act as predisposing factors. Precipitating and perpetuating factors include stress, adjustment reactions, anxiety and depressive episodes. ${ }^{(14)}$ Specific factors such as 
Table II. Primary headache disorders.

\begin{tabular}{|llll|}
\hline Headache features & Tension-type headache & Migraine & Cluster headache \\
\hline Pain location & Bilateral & Unilateral or bilateral & Unilateral (around the eye or along the face) \\
\hline Pain quality & Pressing/tightening & Pulsating/throbbing & Variable \\
\hline Pain intensity & Mild to moderate & Moderate to severe & Severe to very severe \\
\hline Effect on activities & $\begin{array}{l}\text { Not aggravated by routine } \\
\text { activities of daily living }\end{array}$ & $\begin{array}{l}\text { Aggravated by or causes } \\
\text { avoidance of routine activities of } \\
\text { daily living }\end{array}$ & Restlessness or agitation \\
\hline Other symptoms & None & $\begin{array}{l}\text { Nausea or vomiting, unusual } \\
\text { sensitivity to light or sight, } \\
\text { aura (visual, sensory, speech } \\
\text { disturbance) }\end{array}$ & $\begin{array}{l}\text { Cranial autonomic symptoms in same side } \\
\text { as headache (red, watery or swollen eye, } \\
\text { nasal congestion/runny nose, sweating) }\end{array}$ \\
\hline Duration & 4-72 hours & 15-180 minutes \\
\hline
\end{tabular}

Table III. ICHD-3 diagnostic criteria for tension-type headaches, migraines and cluster headaches.

\begin{tabular}{|c|c|c|c|}
\hline No. & Tension-type headache & Migraine & Cluster headache \\
\hline A & $\begin{array}{l}\text { Episodic: } \geq 10 \text { episodes occurring on } \\
<1 \text { day/month on average } \\
\text { Chronic: } \geq 15 \text { days/month for }>3 \\
\text { months on average }\end{array}$ & $\geq 5$ attacks fulfilling criteria B-D & $\geq 5$ attacks fulfilling criteria $B-D$ \\
\hline B & Lasting from 30 minutes to 7 days & $\begin{array}{l}\text { Headache attacks lasting 4-72 hours } \\
\text { (untreated or fully treated) }\end{array}$ & $\begin{array}{l}\text { Severe or very severe unilateral orbital, } \\
\text { supraorbital and/or temporal pain lasting } \\
15-180 \text { minutes (when untreated) }\end{array}$ \\
\hline C & $\begin{array}{l}\geq 2 \text { of the following characteristics: } \\
\text { 1. Bilateral location } \\
\text { 2. Pressing or tightening } \\
\text { (non-pulsating) quality } \\
\text { 3. Mild or moderate intensity } \\
\text { 4. Not aggravated by routine physical } \\
\text { activity such as walking or climbing } \\
\text { stairs }\end{array}$ & $\begin{array}{l}\geq 2 \text { of the following characteristics: } \\
\text { 1. Unilateral location (one-third can be } \\
\text { bilateral) } \\
\text { 2. Pulsating quality } \\
\text { 3. Moderate or severe pain intensity } \\
\text { 4. Aggravated by or causes avoidance } \\
\text { of routine physical activity }\end{array}$ & $\begin{array}{l}\text { Either or both of the following: } \\
\text { 1. - } \geq 1 \text { of the following symptoms or signs, } \\
\text { ipsilateral to the headache: } \\
\text { - conjunctival injection and/or lacrimation } \\
\text { - nasal congestion and/or rhinorrhoea } \\
\text { - eyelid oedema } \\
\text { - forehead and facial sweating } \\
\text { - miosis and/or ptosis } \\
\text { 2. - Sense of restlessness or agitation }\end{array}$ \\
\hline $\mathrm{D}$ & $\begin{array}{l}\text { Both of the following: } \\
\text { 1. No nausea or vomiting } \\
\text { 2. No more than one of photophobia } \\
\text { or phonophobia }\end{array}$ & $\begin{array}{l}\geq 1 \text { of the following during headaches: } \\
\text { 1. Nausea and/or vomiting } \\
\text { 2. Photophobia and phonophobia }\end{array}$ & $\begin{array}{l}\text { Occurs with a frequency of between one } \\
\text { every other day and } 8 \text { per day }\end{array}$ \\
\hline $\mathrm{E}$ & Not attributed to another disorder & Not attributed to another disorder & $\begin{array}{l}\text { Not better accounted for by another } \\
\text { ICHD-3 diagnosis }\end{array}$ \\
\hline
\end{tabular}

ICHD-3: International Classification of Headache Disorders, 3rd edition

\section{Box 1. ID Migraine (1 point for each symptom).}

- Disabling headache

- Photophobia

- Vomiting

Two out of three symptoms being present has a positive predictive value of $93 \%$.

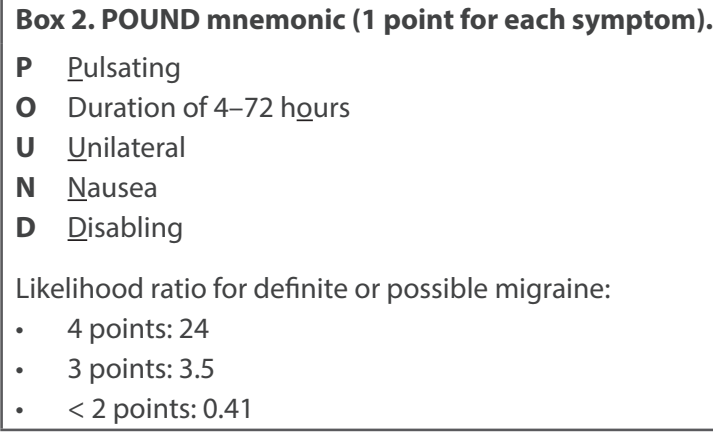

sensory stimuli, menses, medications (e.g. oral contraceptives, vasodilators), and foods (e.g. wine, cheese, salty food) may precipitate and trigger migraine. Prior rapport and familiarity with a patient's pattern of health and illness, borne of a long-term doctor-patient relationship, may allow the primary care physician to readily recognise any underlying psychosocial issues that may present as a change in this pattern. ${ }^{(15)}$ The headache diary is useful for the patient with chronic severe headache. Trigger avoidance, reassurance and patient education are important for successful management. All modifiable factors should be addressed, and medications prescribed as required. Patients who fail to respond to treatment need a review to revisit the diagnosis and/or to address any medication non-adherence or overuse.

\section{Treatment of tension-type headache}

For episodic TTH, simple analgesics such as paracetamol and nonsteroidal anti-inflammatory drugs (NSAIDs) generally suffice 
(Table IV). The use of opioids such as codeine should be carefully considered in view of possible adverse effects such as dependency and medication overuse headache.

Because headache is a common somatoform symptom, ${ }^{(16,17)}$ consider the possibility of underlying mental health issues in the patient who presents with headache, ${ }^{(18,19)}$ especially if the headaches are severe and chronic. When indicated, preventive treatment with tricyclic antidepressants ${ }^{(20,21)}$ or beta-blockers ${ }^{(22)}$ may be considered (Table IV). Start preventers at a low dose and escalate until adequate control is achieved. Patients should be counselled that preventive medications need time to take effect, and that treatment need not be lifelong.

\section{Treatment of migraine}

Simple analgesics may suffice as first-line treatment for acute migraine. Antiemetics may be considered if there is concomitant nausea and vomiting. Second-line treatments include triptans (serotonin 5-hydroxytryptamine type 1B/1D

Table IV. Medication references.

\begin{tabular}{|c|c|c|c|c|c|}
\hline \multicolumn{6}{|l|}{ Acute treatment } \\
\hline Medication & $\begin{array}{l}\text { Usual dose/ } \\
\text { formulation }\end{array}$ & $\begin{array}{l}\text { Maximum } \\
\text { daily dose }\end{array}$ & Avoid/use with caution & May be preferred & Adverse effects \\
\hline Acetaminophen & $1,000 \mathrm{mg}$ & $\begin{array}{l}1,000 \mathrm{mg} \text { TDS/QDS, } \\
\max 4,000 \mathrm{mg}\end{array}$ & Liver dysfunction & $\begin{array}{l}\text { Mild to moderate TTH, } \\
\text { migraine, considered } \\
\text { safe in pregnancy }\end{array}$ & - \\
\hline \multicolumn{6}{|c|}{$\begin{array}{l}\text { NSAIDs } \\
\text { - Avoid in third trimester of pregnancy } \\
\text { - Consider gastroprotection }\end{array}$} \\
\hline Ibuprofen & $400 \mathrm{mg}$ & $\begin{array}{l}400-600 \mathrm{mg} \text {, up to } \\
\text { QDS }\end{array}$ & \multirow{4}{*}{$\begin{array}{l}\text { Asthma or peptic ulcer, } \\
\text { hypersensitivity to } \\
\text { salicylic acid or renal } \\
\text { disease }\end{array}$} & \multirow[t]{3}{*}{$\begin{array}{l}\text { Mild to moderate TTH, } \\
\text { migraine }\end{array}$} & \multirow{4}{*}{$\begin{array}{l}\text { Gl disturbances, } \\
\text { haemorrhage, } \\
\text { hypersensitivity } \\
\text { reactions, } \\
\text { drowsiness }\end{array}$} \\
\hline Naproxen sodium & $550 \mathrm{mg}$ & $550 \mathrm{mg} \mathrm{BD}$ & & & \\
\hline Diclofenac sodium & $50 \mathrm{mg}$ & $50 \mathrm{mg}$ BD-TDS & & & \\
\hline Mefenamic acid & $250 \mathrm{mg}$ & $\begin{array}{l}500 \mathrm{mg} \text { initially, } \\
\text { then } 250 \mathrm{mg} \text { up to } \\
\text { QDS }\end{array}$ & & Menstrual migraine & \\
\hline \multicolumn{6}{|c|}{ Preventive treatment } \\
\hline \multicolumn{6}{|c|}{$\begin{array}{l}\text { - Safety in pregnancy has not been established, although there } \\
\text { - Should not be combined with ergotamines or other triptans }\end{array}$} \\
\hline Sumatriptan & $\begin{array}{l}50 \mathrm{mg} \text { and } \\
100 \mathrm{mg} \text { daily }\end{array}$ & 200 mg daily & $\begin{array}{l}\text { Cerebrovascular or } \\
\text { cardiovascular disease or } \\
\text { hypertension }\end{array}$ & $\begin{array}{l}\text { Moderate to severe } \\
\text { migraine when simple } \\
\text { analgesics have failed }\end{array}$ & $\begin{array}{l}\text { Chest discomfort, } \\
\text { nausea, distal } \\
\text { paraesthesias, } \\
\text { drowsiness or } \\
\text { fatigue, flushing } \\
\text { or sensation of } \\
\text { warmth on face, } \\
\text { neck or jaw }\end{array}$ \\
\hline \multicolumn{6}{|l|}{ Antidepressants } \\
\hline Amitriptyline & $10 \mathrm{mg}$ ON & $10-100 \mathrm{mg} \mathrm{ON}$ & $\begin{array}{l}\text { Heart block, significant } \\
\text { cardiovascular disease, } \\
\text { urinary retention, } \\
\text { uncontrolled glaucoma } \\
\text { (particularly angle } \\
\text { closure type), prostate } \\
\text { disease, mania }\end{array}$ & $\begin{array}{l}\text { Insomnia, depression, } \\
\text { anxiety, neuropathic } \\
\text { pain, first-line } \\
\text { preventive therapy for } \\
\text { TTH and migraine }\end{array}$ & $\begin{array}{l}\text { Weight gain, } \\
\text { drowsiness, } \\
\text { confusion, } \\
\text { anticholinergic } \\
\text { effects (dry } \\
\text { mouth, } \\
\text { constipation), } \\
\text { lower seizure } \\
\text { threshold, sexual } \\
\text { dysfunction, } \\
\text { cardiovascular } \\
\text { effects }\end{array}$ \\
\hline \multicolumn{6}{|l|}{ Beta-blockers } \\
\hline Propranolol & $20 \mathrm{mg} \mathrm{BD}$ & $40-120 \mathrm{mg} \mathrm{BD}$ & $\begin{array}{l}\text { Asthma, heart failure, } \\
\text { peripheral vascular } \\
\text { disease, depression }\end{array}$ & $\begin{array}{l}\text { First-line preventive } \\
\text { therapy for migraines }\end{array}$ & $\begin{array}{l}\text { Asthma, heart } \\
\text { failure, peripheral } \\
\text { vascular disease, } \\
\text { depression }\end{array}$ \\
\hline
\end{tabular}


Table IV. (Contd...)

\begin{tabular}{|c|c|c|c|c|c|}
\hline \multicolumn{6}{|c|}{ Acute treatment } \\
\hline Medication & $\begin{array}{l}\text { Usual dose/ } \\
\text { formulation }\end{array}$ & $\begin{array}{l}\text { Maximum } \\
\text { daily dose }\end{array}$ & Avoid/use with caution & May be preferred & Adverse effects \\
\hline \multicolumn{6}{|c|}{ Antiepileptics } \\
\hline Topiramate & $\begin{array}{l}25 \mathrm{mg} \text { daily, } \\
\text { to increase } \\
\text { by } 25 \mathrm{mg} \\
\text { each week }\end{array}$ & $\begin{array}{l}50 \mathrm{mg} \text { to } 200 \mathrm{mg} \\
\text { daily (divided BD) }\end{array}$ & $\begin{array}{l}\text { Kidney stones, kidney } \\
\text { failure, angle closure } \\
\text { glaucoma } \\
\text { Use with caution in } \\
\text { depression, avoid in } \\
\text { pregnancy, use caution } \\
\text { if combined with } \\
\text { valproic acid (risk of } \\
\text { encephalopathy) }\end{array}$ & $\begin{array}{l}\text { Epilepsy, obesity, } \\
\text { mania, anxiety, } \\
\text { essential tremor, } \\
\text { alcohol dependence, } \\
\text { second-line preventive } \\
\text { therapy for migraines }\end{array}$ & $\begin{array}{l}\text { Gl (nausea, } \\
\text { anorexia), } \\
\text { renal calculi, } \\
\text { paraesthesias, } \\
\text { acute glaucoma, } \\
\text { central nervous } \\
\text { system-related } \\
\text { (dizziness, } \\
\text { tremor, sedation, } \\
\text { cognitive } \\
\text { impairment, } \\
\text { depression), } \\
\text { weight loss, } \\
\text { metabolic } \\
\text { acidosis }\end{array}$ \\
\hline
\end{tabular}

BD: twice daily; GI: gastrointestinal; NSAIDs: nonsteroidal anti-inflammatory drugs; ON: every night; QDS: four times a day; TDS: three times a day; TTH: tension-type headache

receptor agonists) and ergotamine derivatives (Table IV). ${ }^{(23)}$ The combination of triptans and NSAIDs may be superior to either drug alone. ${ }^{(24)}$ If symptoms are recurrent, search for underlying precipitating factors and/or psychiatric conditions. Preventive therapy is indicated if the migraine attacks are: (a) recurrent (> 3 days/month) and cause considerable disability despite optimal acute drug treatment; (b) recurrent with prolonged aura and/or hemiplegic migraine; (c) frequent and require medication usage at levels that risk bringing on medication overuse headache; and (d) recurrent and where acute treatment is contraindicated.

Preventive treatment options include beta-blockers, antidepressants and antiepileptics. ${ }^{(25)}$ A $50 \%$ reduction of the episodic frequency of headache over 6-8 weeks is considered a reasonable treatment target. The long-term aims of preventive treatment are to reduce reliance on acute pharmacological treatment and to minimise the risk of chronic headache setting in. The decision to commence preventive therapy is highly individualised and should be based on the duration and severity of symptoms experienced by the patient, rather than solely on whether the disorder is episodic or chronic. When jointly agreed upon by both doctor and patient, preventive treatment should be initiated at a low dose and increased every 2-3 weeks until effective or dose-limiting side effects occur. Gradual withdrawal may be considered after 6-12 months of successful preventive therapy.

\section{Treatment of medication overuse headache}

Medication overuse headache is defined as a headache that arises from regular medication overuse of three months or more for a pre-existing headache (Box 3). NSAID and paracetamol usage of $\geq 15$ days per month, and triptan and/or opioid usage $\geq 10$ days per month is considered overuse.
Box 3. ICHD-3 diagnostic criteria for medication overuse headache.

A. Headache occurring $\geq 15$ days/month in a patient with a preexisting headache disorder

B. Regular overuse ( $>3 \mathrm{mth}$ ) of one or more drugs that can be taken for acute and/or symptomatic treatment of headache C. Not attributed to another disorder

Most patients with medication overuse headache have an underlying migraine or TTH that is masked by the presence of medication overuse. When suspected, avoid the use of preventive medication: they are generally ineffective and perpetuate medicine overprescription. Medication overuse headache requires deprescription of the overused medications, which for some patients may be achieved only with inpatient care. Evidence shows that for the majority of patients with medication overuse headache, responsiveness to preventive treatment improves after discontinuation of the overused medication. ${ }^{(26)}$ Successful treatment requires careful management of expectations, close follow-up and is dependent on a trusting doctor-patient therapeutic relationship.

\section{WHEN SHOULD I REFER TO A NEUROLOGIST?}

A secondary headache generally requires referral to the emergency department or urgent referral to appropriate specialists (Table I). While patients with cluster headaches and daily headaches should be referred to a neurologist, most primary headaches such as $\mathrm{TTH}$ and migraine may be managed at primary care. Referral to a neurologist for primary headaches should be considered when there is: (a) diagnostic uncertainty; (b) lack of response to two preventive strategies in succession; (c) frequent attendances to manage headache; (d) significant unresolved disability due to 
headache; and (e) prolonged aura, especially an aura that persists after resolution of headache or that involves motor weakness.

\section{TAKE HOME MESSAGES}

1. Headache is common in primary care. Holistic and accurate diagnosis increases quality of life, lowers socioeconomic costs and minimises overprescription.

2. Differentiating secondary from primary headache is key in clinical evaluation. This requires a thorough history and physical examination, including a comprehensive neurological examination.

Ms Lim showed symptoms of medication overuse headache with episodic migraine. Due to the change in her headache, you strongly suggested a referral to neuroimaging to exclude any secondary causes. She adamantly refused, as she was not keen to visit the hospital. You explained the possible diagnosis of medication overuse headache and how it could be managed. You discovered that because of her irregular working hours, she has been snacking more often, sleeping more irregularly and having less frequent meals. She has not exercised for more than six months. You discussed how she could start having more regular sleep and mealtimes, and suggested an exercise regime of at least three times a week. In addition, she agreed to stop taking her analgesics. On subsequent review, the frequency of her headaches had drastically reduced, returning to its previous patterns. You worked with Ms Lim to formulate a treatment strategy for her migraine.

ABSTRACT Headaches are common in primary care. For safe assessment and management of the patient with headache, a focused history and physical examination are important to identify secondary headache, and find out whether an immediate referral to the emergency department or a non-emergent referral to the neurologist is warranted. The majority of patients with primary headache may be safely managed in the outpatient setting. Key steps include proper categorisation of the primary headache, attention to lifestyle and psychosocial factors, prescription of analgesics for acute pain relief, and the use of preventive medication when indicated. The patient with a cluster headache, a headache of uncertain diagnosis and/or poor response to preventive strategies or a migraine with persistent aura, or a headache with associated motor weakness, should be referred to a neurologist. Secondary headache and the diagnosis of medication overuse headache should be considered in a patient on long-term analgesics with unremitting headache.

Keywords: cluster headache, headache, migraine disorder, primary care, tension-type headache
3. Life-threatening secondary headaches should be immediately referred to the emergency department. Secondary headaches and cluster headaches should be referred to the respective specialists.

4. Chronic headaches may be treated and have good outcomes in primary care with the careful use of both preventive and acute pain treatment.

5. Medication overuse headache is underdiagnosed. Successful withdrawal of the overprescribed medication depends on the trust inherent in a collaborative and ongoing therapeutic doctor-patient relationship.

\section{REFERENCES}

1. Diener HC, Steiner TJ, Tepper SJ. Migraine--the forgotten epidemic: development of the EHF/WHA Rome Declaration on Migraine. J Headache Pain 2006; 7:433-7.

2. Edmeads J, Findlay $\mathrm{H}$, Tugwell $\mathrm{P}$, et al. Impact of migraine and tension-type headache on life-style, consulting behaviour, and medication use: a Canadian population survey. Can J Neurol Sci 1993; 20:131-7.

3. Clarke CE, MacMillan L, Sondhi S, Wells NE. Economic and social impact of migraine. QJM 1996; 89:77-84.

4. Von Korff M, Stewart WF, Simon DJ, Lipton RB. Migraine and reduced work performance: a population-based diary study. Neurology 1998; 50: 1741-5.

5. Lipton RB, Silberstein SD. The role of headache-related disability in migraine management: implications for headache treatment guidelines. Neurology 2001; 56(6 Suppl 1):S35-42.

6. Ferrari MD. The economic burden of migraine to society. Pharmacoeconomics 1998; 13:667-76.

7. Global Health Estimates 2016: Disease burden by Cause, Age, Sex, by Country and by Region, 2000-2016. In: WHO Global Health Estimates 2016. Available at: http://www.who.int/healthinfo/global_burden_disease/estimates/en/index1 . html. Accessed July 23, 2018.

8. Ho KH, Ong BK. A community-based study of headache diagnosis and prevalence in Singapore. Cephalalgia 2003; 23:6-13.

9. Khu JV, Siow HC, Ho KH. Headache diagnosis, management and morbidity in the Singapore primary care setting: findings from a general practice survey. Singapore Med J 2008; 49:774-9

10. Dodick DW. Pearls: headache. Semin Neurol 2010; 30:74-81.

11. Headache Classification Committee of International Headache Society (IHS). The International Classification of Headache Disorders, 3rd edition. Cephalalgia 2018; 38:20-27.

12. Lipton RB, Dodick D, Sadovsky R, et al; ID Migraine validation study. A selfadministered screener for migraine in primary care: The ID Migraine validation study. Neurology 2003; 61:375-82.

13. Detsky ME, McDonald DR, Baerlocher MO, et al. Does this patient with headache have a migraine or need neuroimaging? JAMA 2006; 296: 1274-83.

14. Buse DC, Andrasik F. Behavioral medicine for migraine. Neurol Clin 2009; 27:445-65.

15. Maizels M, Burchette R. Somatic symptoms in headache patients: the influence of headache diagnosis, frequency, and comorbidity. Headache 2004; 44:983-93

16. Kroenke K, Spitzer RL, Williams JB, et al. Physical symptoms in primary care. Predictors of psychiatric disorders and functional impairment. Arch Fam Med 1994; 3:774-9.

17. Maizels M, Burchette R. Somatic symptoms in headache patients: the influence of headache diagnosis, frequency, and comorbidity. Headache 2004; 44: 983-993.

18. Gesztelyi G. [Primary headache and depression]. Orv Hetil 2004; 145:2419-24. Hungarian.

19. Chu HT, Liang CS, Lee JT, et al. Associations between depression/anxiety and headache frequency in migraineurs: a cross-sectional study. Headache 2018; 58:407-15.

20. Bigal ME, Rapoport AM, Hargreaves R. Advances in the pharmacologic treatment of tension-type headache. Curr Pain Headache Rep 2008; 12:442-6.

21. Cerbo R, Barbanti P, Fabbrini G, Pascali MP, Catarci T. Amitriptyline is effective in chronic but not in episodic tension-type headache: pathogenetic implications. Headache 1998; 38:453-7.

22. Beran RG. Management of chronic headache. Aust Fam Physician 2014; 43:106-10. 
23. Rapoport AM, Tepper SJ, Sheftell FD, Kung E, Bigal ME. Which triptan for which patient? Neurol Sci 2006; 27 Suppl 2:S123-9.

24. Marmura MJ, Silberstein SD, Schwedt TJ. The acute treatment of migraine in adults: the American Headache Society evidence assessment of migraine pharmacotherapies. Headache 2015; 55:3-20.

25. Silberstein SD, Holland S, Freitag F, et al; Quality Standards Subcommittee of the
American Academy of Neurology and the American Headache Society. Evidencebased guideline update: pharmacologic treatment for episodic migraine prevention in adults: report of the Quality Standards Subcommittee of the American Academy of Neurology and the American Headache Society. Neurology 2012; 78:1337-45. 26. Chiang CC, Schwedt TJ, Wang SJ, Dodick DW. Treatment of medication-overuse headache: a systematic review. Cephalalgia 2016; 36:371-86. 


\section{SINGAPORE MEDICAL COUNCIL CATEGORY 3B CME PROGRAMME} (Code SMJ 201808A)

1. Medication overuse headache is largely unrecognised in Singapore.

2. Preventive medication is often prescribed for chronic headaches in Singapore.

3. Secondary headaches are rare and account for $1 \%$ of all headaches.

4. A new-onset headache is a cause for concern in a 56-year-old woman, as it may indicate serious secondary causes.

5. The three items in ID Migraine include nausea, disabling headache and phonophobia.

6. Most migraines have an associated aura.

7. A migraine cannot be bilateral.

8. Headaches can be due to psychosocial factors.

9. Panadeine (paracetamol and codeine) is recommended for headaches.

10. If a patient does not respond to paracetamol and nonsteroidal anti-inflammatory drugs, tramadol should be prescribed.

11. Once started on preventive therapy, a patient has to be on lifelong medication.

12. Preventive therapy takes $1.5-2$ months to take effect.

13. Patients with medication overuse headache often have an underlying migraine or tension-type headache.

14. Treatment of medication overuse headache involves withdrawal of the offending medications.

15. Excessive caffeine can precipitate headache.

16. Fundoscopy to look for papilloedema is not important in the examination of patient presenting with headache.

17. Patients with cluster headaches should be referred to a neurologist.

18. Patients with migraines are often unable to carry out activities of daily living during attacks.

19. Headache is not a common presentation of somatoform symptoms.

20. Headache can be managed well in primary care.

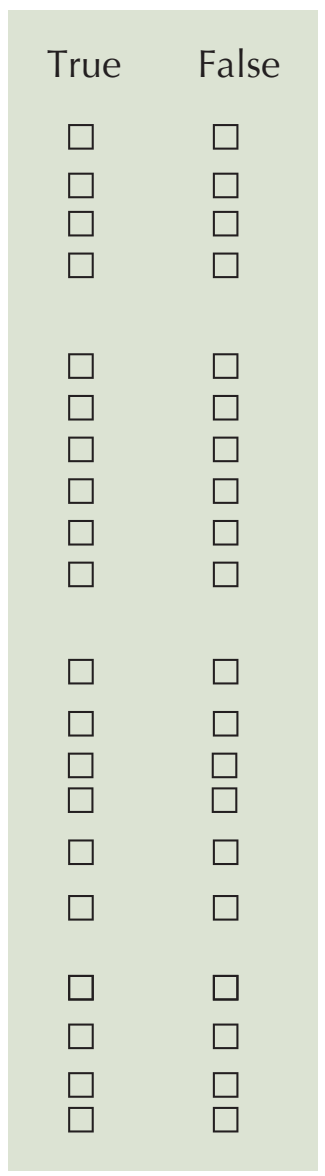

\section{Doctor's particulars:}

Name in full:

Specialty:

MCR no.:

Email:

\section{SUBMISSION INSTRUCTIONS}

Visit the SMJ website: http://www.smj.org.sg/current-issue and select the appropriate quiz. You will be redirected to the SMA login page.

For SMA member: (1) Log in with your username and password (if you do not know your password, please click on 'Forgot your password?'). (2) Select your answers for each quiz and click 'Submit'.

For non-SMA member: (1) Create an SMJ CME account, or login with your SMJ CME username and password (for returning users). (2) Make payment of SGD 21.40 (inclusive of $7 \%$ GST) via PayPal to access this month's quizzes. (3) Select your answers for each quiz and click 'Submit'.

\section{RESULTS:}

(1) Answers will be published online in the SMJ October 2018 issue. (2) The MCR numbers of successful candidates will be posted online at the SMJ website by 12 October 2018. (3) Passing mark is $60 \%$. No mark will be deducted for incorrect answers. (4) The SMJ editorial office will submit the list of successful candidates to the Singapore Medical Council. (5) One CME point is awarded for successful candidates. (6) SMC credits CME points according to the month of publication of the CME article (i.e. points awarded for a quiz published in the December 2017 issue will be credited for the month of December 2017, even if the deadline is in January 2018).

Deadline for submission (August 2018 SMJ 3B CME programme): 12 noon, 5 October 2018. 